\title{
Duygusal Zekânın Etkili Liderlik Üzerine Etkisi: Türkiye ve Afganistan Üzerine Karşılaştırmalı Bir Çalışma \\ (Impact of Emotional Intelligence on Effective Leadership: A Comparative Study of Turkey and Afghanistan)
}

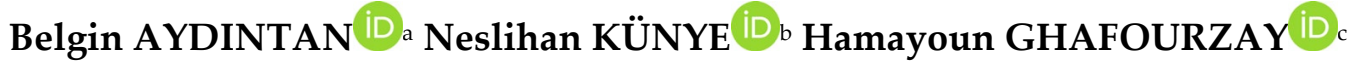 \\ a Ankara Hacı Bayram Veli Üniversitesi, İktisadi ve İdari Bilimler Fakültesi, Ankara, Türkiye. belginaydintan@gmail.com \\ b Ankara Hacı Bayram Veli Üniversitesi, Eğitim Bilimleri Enstitüsü, Ankara, Türkiye. nkunye@gmail.com \\ c Ankara Hacı Bayram Veli Üniversitesi, Eğitim Bilimleri Enstitüsü, Ankara, Türkiye. hamayoun.ghafourzay@yahoo.com
}

\begin{tabular}{|c|c|}
\hline MAKALE BİLGİSİ & ÖZET \\
\hline $\begin{array}{l}\text { Gönderme Tarihi } 26 \text { Aralık } 2018 \\
\text { Revizyon Tarihi } 10 \text { Mayıs } 2019 \\
\text { Kabul Tarihi } 25 \text { Mayıs } 2019\end{array}$ & $\begin{array}{l}\text { Amaç - Çalışmanın amacı, duygusal zekânın etkili liderlik üzerindeki etkisinin ülkelerarası } \\
\text { farklılıklar açısından incelenmesidir. } \\
\text { Yöntem - Çalışma, Türkiye ve Afganistan'da bankacılık, eğitim (üniversite), savunma, sağlık } \\
\text { gibi kamu ve özel kesimde yer alan çeşitli sektörler üzerinde kolayda örneklem yoluyla seçilmiş } \\
\text { kişiler üzerinde yapılmıştır. Araşırmada veriler anket yöntemi yardımıyla toplanmış olup } \\
\text { veriler SPSS } 11.5 \text { istatistik programı yardımıyla analiz edilmiştir. Analizlerde Frekans Analizi, } \\
\text { Korelasyon Analizi ve Doğrusal Regresyon Analizinden faydalanılmıştır. } \\
\text { Bulgular - Yapılan analizler neticesinde her iki ülkede de (Türkiye ve Afganistan) duygusal } \\
\text { zekâ ve etkili liderlik arasında anlamlı pozitif yönlü bir ilişki görülmüştür (Türkiye için \%63,1 } \\
\text { ve Afganistan için \%59 düzeyinde ilişki). Aynı zamanda duygusal zekânın etkili liderlik } \\
\text { üzerinde etkili olduğu görülmüştür. } \\
\text { Tartışma - Yönetimin tarihi sürecine bakıldığında yönetici/lider ve insan ilişkilerinin birbiriyle } \\
\text { yakın ilişkide olduğu ve birlikte ele alındığı görülmektedir. Günümüzde yönetici/liderin } \\
\text { özellikleri ele alındığında yapılan çalışmalarda etkili liderlik için gerekli olan unsurların en } \\
\text { önemlilerinden biri kişinin duygusal zekâ düzeyinin olduğu ortaya çımıştır. Duygusal zekâ } \\
\text { etkili liderlik için neden bu kadar önemlidir? Robbins ve Judge (2015), duygusal zekânın } \\
\text { savunucularının; duygusal zekâya sahip olmayan kişinin çok iyi bir eğitime, yüksek derecede } \\
\text { analitik zekâya, geniş vizyona ve sınırsız sayıda güzel fikirler üreten özelliklere sahip olsa da } \\
\text { büyük lider olamayacaklarını iddia etmekte olduğunu ifade etmiştir. Burada liderliğin } \\
\text { özelliklerine bakıldığında liderin kişisel ve akademik becerilerinin yanında duygu yapısının da } \\
\text { incelenmesi etkin bir lider olabilmesi açısından önem arzetmektedir. Bu bağlamda çalışmanın } \\
\text { amacını duygusal zekâ ile etkili liderlik arasındaki ilişkinin ülkelerarası farklılıklar açısından } \\
\text { incelenmesi oluşturmaktadır. }\end{array}$ \\
\hline
\end{tabular}

\begin{tabular}{|c|c|}
\hline ARTICLE INFO & ABSTRACT \\
\hline $\begin{array}{l}\text { Keywords: } \\
\text { Emotional Intelligence } \\
\text { Effective Leadership } \\
\text { Leadership }\end{array}$ & $\begin{array}{l}\text { Purpose - The purpose of the study is to examine the relationship between emotional } \\
\text { intelligence and effective leadership in terms of inter-country differences. } \\
\text { Design/methodology/purpose - For examining the mentioned purpose an empirical study with } \\
\text { convenience sampling method was carried out on both private and public sectors such as } \\
\text { education (university), banking, defense and health at Turkey and Afghanistan. The gathered } \\
\text { data through survey method were analyzed by SPSS } 11.5 \text { statistical program to test the } \\
\text { proposed hypothesis. The frequency analysis, correlation analysis, and linear regression } \\
\text { analysis were used to analyze the collected data. } \\
\text { Finding - As the result of the analysis in both countries (Turkey and Afghanistan), a significant } \\
\text { positive correlation was observed between emotional intelligence and effective leadership } \\
\text { (Turkey: } 63.1 \% \text { and Afghanistan: } 59 \% \text { ). At the same time, emotional intelligence has been } \\
\text { shown to have an impact on effective leadership. } \\
\text { Discussion - In the history of Management, it is seen that managers/leaders and human } \\
\text { relations are closely related and discussed together. Nowadays, in the studies which consider } \\
\text { the characteristics of managers/leaders, one of the most important elements for effective }\end{array}$ \\
\hline
\end{tabular}

Önerilen Atıf/ Suggested Citation:

Aydıntan, B., Künye, N., Ghafourzay, H. (2019). Duygusal Zekânın Etkili Liderlik Üzerine Etkisi: Türkiye ve Afganistan Üzerine

Karşılaştırmalı Bir Çalışma, İşletme Araştırmaları Dergisi, 11 (2), 976-989. 


\begin{abstract}
leadership has emerged as the emotional level of human being. Why is Emotional İntelligence (EI) so critical to effective leadership? Advocates of EI argue that without it, a person can have outstanding training, a highly analytical mind, a compelling vision, and an endless supply of terrific ideas but still not make a great leader. This may be especially true as individuals move up in an organization (Robbins and Judge, 2015). To be an effective leader it is important to explore the leader's personal and academic skills as well as the emotional intelligence which becomes a measure for identifying effective leadership and tool for developing effective leadership skills. In this context, the aim of the study is to examine the relationship between emotional intelligence and effective leadership in terms of inter-country differences.
\end{abstract}

\title{
1. Giriş
}

Yönetim alanında insan duygularının gözardı edildiği geleneksel yaklaşımda insana yön veren ve onu motive eden unsurlar, işin ne zaman ve nasıl yapılması gerektiğiyle ilgili bir takım prosedürler ve mesleki yeterlilikler olmaktaydı. Ancak devam eden süreçte yapılan çalışmalarda (Bar-On (2006), "The Bar-On Model of Emotional- Social Intelligence-ESI", Goleman and Boyaztzis (2008), "Social İntelligence and the Biology of Leadership") kişiyi motive eden ve dolayısıyla başarıya ulaştıran en önemli hususlardan birinin insanın duygusal yapısı olduğu ortaya çıkmıştır. Duygusal zekâ etkili liderlik için neden bu kadar önemlidir? Robbins ve Judge (2015), duygusal zekânın savunucularının; duygusal zekâya sahip olmayan kişinin çok iyi bir eğitime, yüksek derecede analitik zekâya, geniş vizyona ve sınırsız sayıda güzel fikirler üreten özelliklere sahip olsa da büyük lider olamayacaklarını iddia etmekte olduğunu ifade etmiştir. Burada liderliğin özelliklerine bakıldığında liderin kişisel ve akademik becerilerinin yanında duygu yapısının da incelenmesi etkin bir lider olabilmesi açısından önem arzetmektedir.

Son yıllarda yönetim alanında yapılan çalışmalarda (Palmer v.d. (2001) "Emotional İntelligence and Effective Leadership", McKeown ve Bates (2013) "Emotion İntelligent Leadership Findings from Study of Public Library Branch Managers in Northern Ireland", Riggio ve Reichard (2008) "The Emotional and Social İntelligences of Effective Leadership. An Emotional and Social Skill Approach") duygusal zekânın liderlik üzerindeki etkileri incelenmiş ve duygusal zekânın başarılı liderlik üzerinde etkisi olduğu ve yüksek duygusal zekâya sahip bireylerin daha iyi performans gösterdiği ileri sürülmüştür. Literatürde duygusal zekâ ve liderlik arasındaki çalışmalarda "etkili liderlik" kavramı liderlik türlerinin çerçevelenmesinde yaşanan bir takım belirsizliklerden dolayı pek fazla ele alınmamıştır. Bu bağlamda çalışmanın amacını duygusal zekâ ile etkili liderlik arasındaki ilişkinin ülkelerarası farklılıklar açısından incelenmesi oluşturmaktadır. Bu amaçla çalışmanın ilerleyen bölümlerinde duygusal zekâ ve etkili liderlik tanımı özellikleri üzerinde durulmuş olup duygusal zekâ ve etkili liderlik arasındaki ilişki istatistiksel yöntemle incelenmiş ve karşılaştırmalı olarak etkin bir literatür taraması yapılmıştır.

\section{Kavramsal Çerçeve}

\subsection{Duygusal Zekâ}

Duygusal zekânın tarihi gelişimine bakıldığında örgütlerdeki mekanik anlayışın yerini insan odaklı anlayışa bırakmasıyla birlikte ortaya çıtığı söylenebilir. Katz ve Kahn (1977: 376), yalnızca tüzükte ve yönetmelikte yer alan davranış koşullarına göre yönetilen bir örgütün "kolay kırılan bir sosyal sistem" oluğunu ifade etmiş ve bir kişinin işe alınırken işbirliğine yönelik ilişkileri konusundaki yeteneğinin de dikkate alınması gerektiğinin altını çizmiştir. Bu bağlamda özellikle yöneticilik kadrosunda bulunan kişilerin teknik becerilerinin yanında insan ilişkileri becerilerinin örgüt için gerekli bir unsur olduğu ortaya çıkmaktadır.

Bununla birlikte Duygusal Zekâ kavramı ilk olarak 1985'te ABD'de bir doktora öğrencisi olan Payne, Wayne Leon'un "A Study of Emotion: Developing Emotional Intelligence; Self-integration; Relating to Fear, Pain and Desire (Theory, Structure of Reality, Problem-Solving, Contraction/Expansion, Tuning in/Coming out/Letting go"(Duygu Üzerine Bir Çalışma: Duygusal Zekâyı Geliştirmek; Korku, Acı ve Arzuya Dair Kendini Bütünleme (Teori, Gerçekliğin Yapısı, Problem Çözme, Daralma/Genişleme, Ayarlama/Ortaya Çıkma/Salıverme) adlı çalışmasında duyulmuştur (Beceren, 2012: 60). 


\section{B. Aydıntan - N. Künye - H. Ghafourzay 11/2 (2019) 976-989}

Tarhan (2014: 20), insan ilişkilerinin temeline bakıldığında, kişiyi şekillendiren olgunun duygusal yapı olduğunu ifade ederken; karşı tarafa söylenenlerden çok nasıl söylendiğinin kişi üzerinde bıraktığı etkiyi araştırmıştır. Örneğin, kızgınlık, korku, heyecan ya da sevinç gibi duygular vücutta kasların gerilmesi, dişlerin sıkılması, göğsün kabarması gibi birtakım kimyasal değişimlere neden olmaktadır. Kişinin bu kimyasalları doğru bir şekilde üretip yönetmesini "duygusal zekâ" olarak tanımlamıştır. Goleman (2007) duygusal zekâyı kişin kendisini harekete geçirebilmesi, duygu durumunu kontrol edebilmesi, sıkıntılı durumlarda olumsuzlukların kendisini ele geçirmesine izin vermemesi, empati yapabilmesi olarak tanımlamaktadır. Duygusal zekânın ortaya çıkış nedeninin mantığın etkisinin azalması değil, insan kalbinin çalışması olarak ifade eden Kılıçarslan (2010: 31), duygusal farkındalığın kişinin gerektiğinde gerçek hislerine ulaşmasını sağladığını ancak bu farkındalığın eksik olduğu durumlarda kişinin duygularını tanımlamakta zorlanacağı ve kontrol edemeyeceğini belirtmiştir.

Tarhan (2014: 22), duygusal zekâyı on temel adımda sınıflandırmış ve bu adımların zihinsel ustalık ve duygusal bilgelik gerektirdiğini belirtmiştir. Bu temel adımlar şu şekilde verilmiştir;

- Öz-bilinç (Kendini tanıma),

- Öz-denetim (Dürtülerini kontrol etme),

- Duyguları ifade edebilme,

- Başkalarının duygularını anlayabilme (Empati),

- Engellere rağmen yola devam edebilme (Sebat),

- Kendini harekete geçirebilme (Motivasyon),

- Uyum sağlayabilme, sorun çözmeye istekli olma,

- Uzlaşmacı olabilme, çözüm odaklı düşünme,

- Ümidi ayakta tutma ve iyimser olma,

- Yeni deneyimlere açık olma, kendini gerçekleştirmeye istek duyma.

Kets de Vries (2007: 47), “...bir kuruluşta zaman içinde bir gram duygunun binlerce ton olgudan daha etkin olduğunu..." belirtirken duygusal zekânın başlıca üç bileşenini şu şekilde vermiştir;

1. Kendi duygularımızı bilir hale gelmek

2. Bu duyguları yönetmeyi öğrenmek

3. Başkalarının duygularını fark etmeyi ve onlarla ilgilenmeyi öğrenmek

Bununla birlikte Kets de Vries (2007: 54) duygusal zekâya sahip olan bireylerin şu özellikleri bünyelerinde barındırdıklarını ifade etmiştir;

- Daha sağlam kişiler arası ilişkiler geliştirirler,

- Kendilerini ve başkalarını motive etmede daha iyidirler,

- Buluşçu ve yaratıcıdırlar,

- Daha etkin liderlik yaparlar,

- Baskı altında daha iyi çalışırlar,

- Değişimle daha iyi başa çıkarlar,

- Kendileriyle daha barışıktırlar.

Duygusal zekâ kavramı konusunda yapılan tanımlamalara bakıldığında, duygusal zekâya sahip olan bireylerin diğer kişilerle pozitif yönlü bir bağ kurabildiği diğer bir deyişle empati yeteneğine sahip oldukları, uyum kaabiliyetinin yüksek olduğu ve işbirliği konusunda gönüllü bir yapıda oldukları söylenebilir. Yapılan bu tanımlamalardan sonra aşağıda birtakım duygusal zekâ modellerine değinilmiştir.

\subsection{Etkili Liderlik}

Liderlik üzerine birçok çalışma yapılmış ve bunun sonucu olarak da liderlikle ilgili farklı tanımlar yer almaktadır. Örneğin Yukl (1999: 34) "An Evaluative Essay on Current Conceptions of Effective Leadership" çalışmasında, liderlik davranışının kavramsallaştırımlasında 1950'lerden 1970'lere kadar görev ve ilişki açısından ele alındığını ancak Ohio Eyaleti Liderlik çalışmalarıyla görev ve ilişki davranışlarının farklı boyutlar olduğunu (örneğin amaç-yol teorisi, liderliğe ikameler yaklaşımı, koşul bağımlılık kuramı gibi) ifade etmiştir. Girdauskiene ve Eyvazzade (2015: 13) "The profile of an effective female leadership in multicultural context" çalışmalarında, hiçbir liderliğin sonuçlara odaklanmadan etkili olarak 


\section{B. Aydıntan - N. Künye - H. Ghafourzay 11/2 (2019) 976-989}

adlandırılamayacağını yani, etkili bir liderin sonuçlara göre çalışabilmesi için kişisel yönetim özelliklerine sahip olması gerektiğini vurgulamışlardır.

Aynı zamanda liderlik türleri bilim adamları tarafından birçok boyutta ele alınmış ve farklı farklı liderlik türleri tasnifine gidilmiştir. Örneğin Robbins (2015) liderliği, kişisel yetenek ve özelliklere, kişilerin karakterstik yapılarına odaklanan Özellikler Teorisi, liderleri lider olmayan kişilerden ayıran davranışları öneren Davranışçı Teori ve Fiedler'in (1977) Durumsal Liderlik Teori'si olarak üç ana başlık altında incelemiştir. Bununla birlikte; kişinin belirli davranışların belirli sonuçlara götüreceğini ifade eden House'ın (1996) Amaç-Yol yaklaşımı, Mc Gregor'un X-Y Kuramı'nı ele almıştır. Diğer yandan Yukl (1999: 36) liderliği “Dönüşümcü (Transformational) ve İşlemsel (Transactional) Liderlik " olarak ele almıştır. Bass (1997) "Dönüşümcü (Transformational) Liderlik" gelişimi tarzı üzerine yoğunlaşmıştır. Dönüşümün amacını, insanları değiştirmek ve liderin takipçileri üzerinde amaç farkındalığı oluşturarak onları cesaretlendirip davranışlarıyla görüşlerini uyumlu hale getirmeye çalışmak olarak belirtmiştir.

Söz konusu yapılan bu çalışmada ise "Etkili Liderlik" kavramı üzerinde durulmuştur.

Etkili liderliğin tanımını yapmadan önce Goleman'ın liderlik üzerine yapmış olduğu tanımı vermekte yarar vardır. Goleman (2003: 193) liderliği, "Hükmetmek değil; insanları ortak bir hedef doğrultusunda birlikte çalışmaya ikna edebilmek" olarak nitelendirmiştir. Bununla birlikte yaptığımız iş hakkında beslediğimiz duyguların ve işten daha fazla verim alabilmek için yapmamız gereken değişikliklerin farkında olmamızın etkili liderlik için son derece hayati olduğunu vurgulamıştır.

Goetsch (2005: Viii) “Etkili liderlik, insanlara örgütsel hedefleri başarmak ya da aşmak için istekli ve gönüllü bir taahhütte bulunma konusunda ilham verme becerisidir" şeklinde bir tanımlamada bulunmuştur.

Liderlik alanında literatüre çok sayıda eser kazandırmış olan John Adair (2003: 41) "Esin Veren Lider" adlı çalışmasında liderliğin üç anahtar işlevinden bahsetmektedir. Bunlar;

- Ortak görevi başarma gereksinimi

- Bir çalışma ünitesi (veya takım) olarak bir arada bulunma gereksinimi

- İnsan olmanın onuruyla bireylerin beraberlerinde grup içine getirdiği gereksinimler

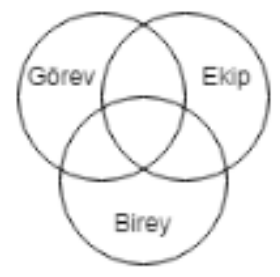

Bunların aslında iç içe geçmiş ve etkileşimli gereksinim alanlarından oluşan bir üçlü seti olduğu görülmektedir.

$\mathrm{Bu}$ üç alanın tatmin edilmesi gerektiğinde "Planlama, Harekete Geçirmek, Kumanda, Destekleme, Bilgi Verme ve Değerlendirme" işlevlerini yerine getirmesi gerekmektedir (Adair, 2003: 42).

Örgütsel davranış alnında özellikle liderlik üzerine birçok çalışma yapmış olan Yukl (2012: 68), Effective Leadership: What We Know and What Questions Need More Attention" adlı çalışmasında etkili liderlik davranışı üzerinde durmuş ve liderlik davranışının hiyerarşik sınıflandırmasını yapmıştır. Bu sınıflandırmaya göre (Tablo 1'de görülmektedir.) bu davranışlar; 1.Görev Odaklı, 2.İlişki odaklı 3.Değişim Odaklı ve 4.Dışsal Liderler olarak gruplandırılmıştır. Bu davranışlar birbirleriyle etkileşim halindedir ve etkili lider bulunduğu duruma göre bu davranışlardan hangisinin uygun olduğuna karar verecektir. 


\section{B. Aydıntan - N. Künye - H. Ghafourzay 11/2 (2019) 976-989}

Tablo 1. Liderlik Davranışının Hiyerarşik Sınıflandırılması (Yukl, 2012:68).

\begin{tabular}{|c|c|}
\hline \multirow{4}{*}{ Görev Odaklı } & Açıklama \\
\hline & Planlama \\
\hline & Gözetim \\
\hline & Problem çözme \\
\hline \multirow{4}{*}{ İlişki Odaklı } & Destekleme \\
\hline & Gelişim \\
\hline & Tanıma \\
\hline & Güçlendirici \\
\hline \multirow{4}{*}{ Değişim Odaklı } & Değişimi savunan \\
\hline & Öngörü sahibi \\
\hline & Yeniliği teşvik etmek \\
\hline & Toplu öğrenmeyi kolaylaştırma \\
\hline \multirow{3}{*}{ Dişsal } & A ğ kurma \\
\hline & Diş gözetim \\
\hline & Temsil etmek \\
\hline
\end{tabular}

Yukl, etkili liderlik için genel üç özellikten bahsetmiştir. Metot, süreç, prosedürler ve etkinlik için gerekli olan araç gereç kullanımı gibi yetileri kapsayan "Teknik Beceriler". İnsan davranışı ve kişiler arası ilişkilerde tutumlar, davranışlar, empati duygusu, diğerlerini anlayıp motive edebilme, etkili ve açık bir iletişim (güzel konuşma, diplomasi, dinleme becerisi, sosyal davranışlar hakkında bilgiler) gibi yetileri kapsayan "Kişilerarası Beceriler". Son olarak da genel analitik beceri, mantıksal düşünme, karmaşık ve belirsiz ilişkilerin kavramsallaştırılmasında uzmanlık, problem çözmede yaratıcılık, değişimleri ve potansiyel sorunları tahmin etmek gibi becerilerin olduğu "Kavramsal Beceriler"dir (Yukl,2013: 155). Etkili liderin yönetimsel becerilerini, duygusal zekâ (Emotional Intelligence), sosyal zekâ (Social Intelligence) ve öğrenme becerisi (Learning Ability) olarak vermiştir.

Bununla birlikte Yukl (1977: 152) örgütsel davranış ve personel psikolojisi adlı çalışmasında etkili liderlikten ilk defa bahsetmiş olup etkili lider için güç (power) kavramının çok önemli ancak bir o kadar da dikkatli kullanılması gereken bir kavram olduğunu vurgulamıştır. Güç, etkili bir lider için örneğin astların organizasyonun amaç ve hedefleri doğrultusunda motive olduğu durumlarda önemli değilken, yine astların organizasyonun amaç ve hedeflerinden saptığında, liderin fikirlerine karşı geldikleri durumda onları motive etmek ve işbirliği konusunda ikna etmek açısında oldukça önemlidir.

Ayrıca Yukl'un (2013: 146) etkili liderlikle ilgili vermiş olduğu birtakım özellikler şu şekildedir;

- Yüksek enerjilidir ve strese karşı toleranslıdır,

- İç kontrol denetimi,

- Duygusal olgunluk,

- Kişisel bütünlük,

- Sosyalleşmiş motivasyon gücü,

- Yüksek başarı,

- Yüksek özgüven,

- Düşük bağlanma ihtiyacı.

Imboden'in (2014: 963), etkili liderlik modelinde Şekil 1'de görüldüğü gibi etkili liderliği "kalite, iş kültürü ve yenilik" olmak üzere üç alan üzerine kurmuştur. Bu alanlar gerekli becerilerin geliştirilmesi, liderliğin adlandırılması, yönetim ve girişimci becerileridir. Liderlik vasfıyla, etkinliği artırmak (doğru olanı yapmak); yönetim vasfıyla, verimliliği arttırmak (işleri doğru yapmak) ve girişimci vasfıyla, şirketi geliştirmek (yeni 


\section{B. Aydıntan - N. Künye - H. Ghafourzay 11/2 (2019) 976-989}

şeyler yapmak). Bu modeli Imboden "Deming Döngüsü"nden (planla, yap, kontrol et, harekete geç) yola çıkarak hazırlamıştır.

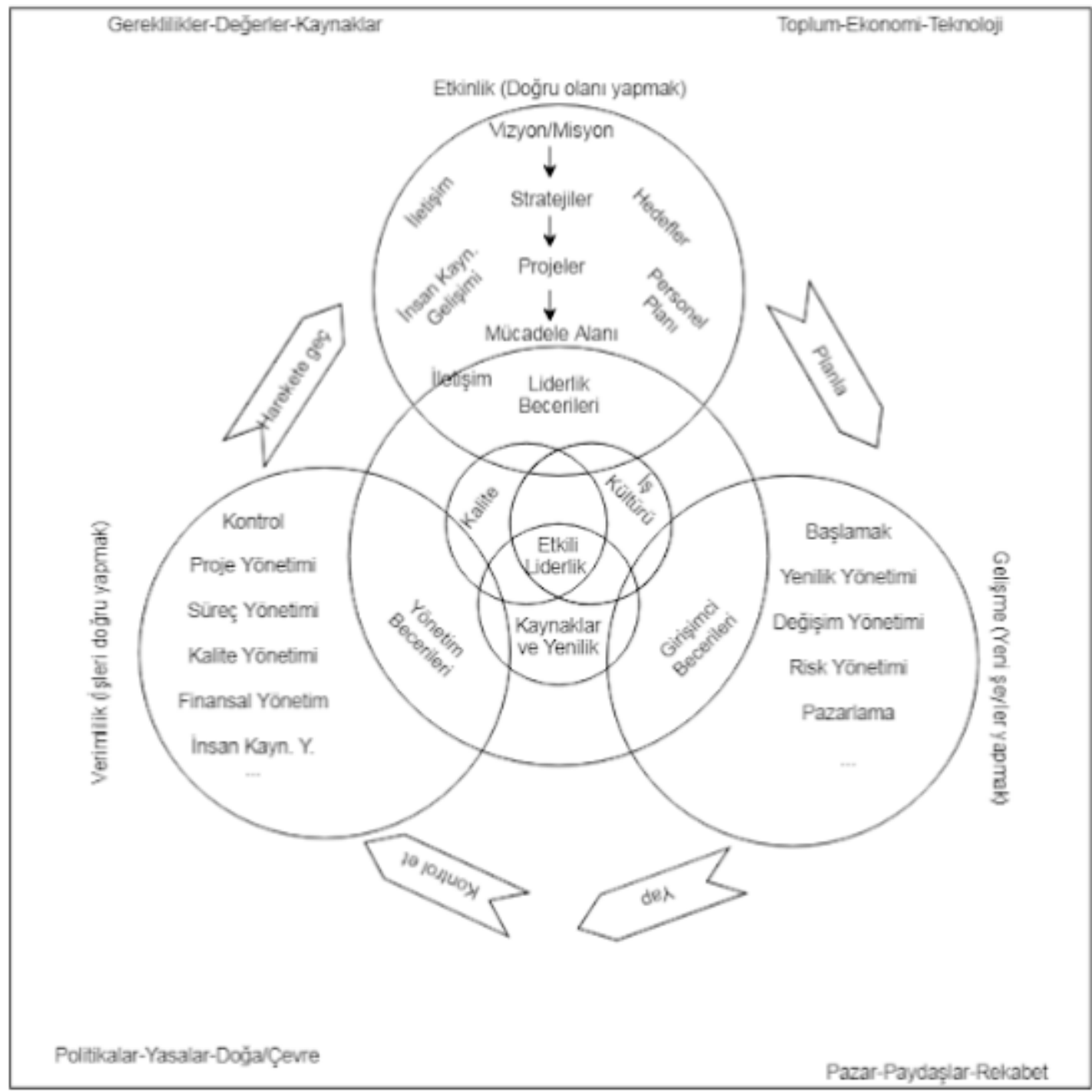

Şekil 1. Etkili Liderlik Modeli (Imboden, 2014: 963)

\subsection{Duygusal Zekâ ve Etkili Liderlik İlişkisi}

Liderlik özelliklerine bakıldığında bir liderin etkin bir lider olabilmesi için; insanları yönetirken, onları motive ederken, rutin toplantı ve görüşmeler gibi kişilerle iletişim halinde olduğu her an bu davranışlarını yerine getirirken kontrollü olması son derece önemlidir. Dolaysıyla burada liderin duygusal zekâsı devreye girmektedir.

Bloch ve Whiteley (2007: 79), empati gösterme, kendini ve başkalarını yönetme, öz-bilinç, etki ve güven çerçevesinde inşa edilen davranış ve tutumlar gibi özelliklerin yönetici seçimi ve terfisinde giderek daha çok kullanılan ölçütler haline geldiğini belirtmişlerdir. Dolayısıyla bu ölçüler etkili liderlik özellikleriyle de uyuştuğundan duygusal zekânın etkili lider için olmazsa olmazı denilebilir.

Başarılı liderler duygularını nasıl yöneteceklerini ve başkalarının duygularını okumayı bilirler. Empati duyguları, liderin etkinliğini sağladığı gibi gerçeklik duygusuna sahip oldukları için güçlü ve zayıf yanlarının farkında olmalarını da sağlar. Neyin arkasında durduklarını ve ilişkileri nasıl yöneteceklerini iyi bilirler (Kets de Vries, 2007: 210). 


\section{B. Aydıntan - N. Künye - H. Ghafourzay 11/2 (2019) 976-989}

Theodore Roosevelt'in (Kets de Vries, 2007: 272) “İyi bir lider, yapılmasını istediği şeyi yapacak kadar, iyi adamları göreve seçecek kadar sezgisi olan, aynı zamanda görevlerini yaparken onların işine karışmayacak kadar geri durmayı bilen kişidir" tanımına bakıldığında etkili bir liderin sahip olması gereken duygusal zekâya atıf yaptı̆̆ını görmekteyiz.

Literatüre bakıldığında duygusal zekânın liderlik türleri üzerindeki etkisini inceleyen birçok çalışma bulunmaktadır. Bunlardan çoğu duygusal zekânın dönüştürücü liderlik ve etkileşimsel liderlik üzerine etkilerini inceleyen çalışmalardır. Erkuş ve Günlü'nün (2008) “Duygusal Zekânın Dönüşümcü Liderlik Üzerine Etkileri”, Leban ve Zulauf'un (2004) "İntelligence Abilities and Transformational Leadership Style", Downey v.d.'nin (2005) "Examinin The Relationship Between Leadership, Emotional İntelligence and İntution in Senior Female Managers" gibi çalışmalar bunlara örnek verilebilir.

Duygusal zekânın etkili liderlikle ilişkisini inceleyen birtakım araştırmalar bu çalışmanın teorik kısmında yer yer metin içinde verildiği gibi önemli birkaçı da şu şekilde sıralanabilir:

Palmer v.d.nin (2001) yapmış oldukları çalışmada duygusal zekâ ve etkili liderlik arasındaki ilişki incelenmiştir. Duygusal zekâyı ölçmek için Salovey'in (1995) Trait Meta Mood Scale (TMMS) ve etkili liderlik için de Avolio'nun (1995) The Multifactor Leadership Questionnaire (MLQ) ölçeğini kullanmışlar ve dönüştürücü liderliğin duygusal zekâda etkileşimsel liderlerden daha yüksek olacağ öngörülmüştür. McKeown ve Bates'in (2013) çalışmasında iletişim, ekip çalışması, işbirliği, uyum, bütünlügünü/güvenilirlik ve öz-farkındalık gibi beş liderlik özelliği incelenmiş olup duygusal zekâ konusunda personelle empati kurmanın önemli olduğu ortaya konmuştur. Riggio ve Reichard (2008), etkili liderlik ve yönetimde duygusal ve sosyal becerilerin rolünü kavramsallaştırmaya yönelik bir çerçeve oluşturmuş ve duygusal becerilerin liderlik geliştirme programının önemli bir bileşeni olabileceğini öne sürmüşlerdir. Ayrıca araştırma sonuçları, duygusal ve sosyal becerilerin hem lider etkinliği ile ilgili olduğunu hem de eğitim müdahaleleri yoluyla geliştirilebildiğini göstermiştir. Gardner ve Stough (2002) üst düzey yöneticilerin liderlik ve duygusal zekâları arasındaki ilişkiyi inceleyen bir çalışma yapmış olup dönüştürücü liderlik ile duygusal zekâ düzeyleri arasında güçlü bir ilişki olduğu; bırakınız yapsınlar/liberal liderlik (laissez faire) ile duygusal zekâ arasında negatif bir ilişki olduğu; etkileşimsel liderlik ve duygusal zekâ arasında ise hiçbir ilişki bulunmadığı sonucuna varmışlardır.

\section{Yöntem}

Bu çalışmanın amacı duygusal zekânın etkili liderlik üzerindeki etkisini incelemek olup çalışmanın hipotezi aşağıdaki gibi verilebilir;

H1: Duygusal zekânın etkili liderlik üzerinde etkisi vardır.

Çalı̧̧ma, Türkiye ve Afganistan'da bankacılık, eğitim (üniversite), savunma, sağlık gibi kamu ve özel kesimde yer alan çeşitli sektörler üzerinde kolayda örneklem yoluyla seçilmiş kişiler üzerinde yapılmıştır. Karşılaştırmanın daha sağlıklı olabilmesi için örneklem sayısı aynı tutulmuş olup Türkiye için 100 adet ve Afganistan için 100 adet anket değerlendirmeye alınmıştır.

Araştırmada ele alınan modelin şematik hali aşağıda gösterilmiştir. 
B. Aydıntan - N. Künye - H. Ghafourzay 11/2 (2019) 976-989

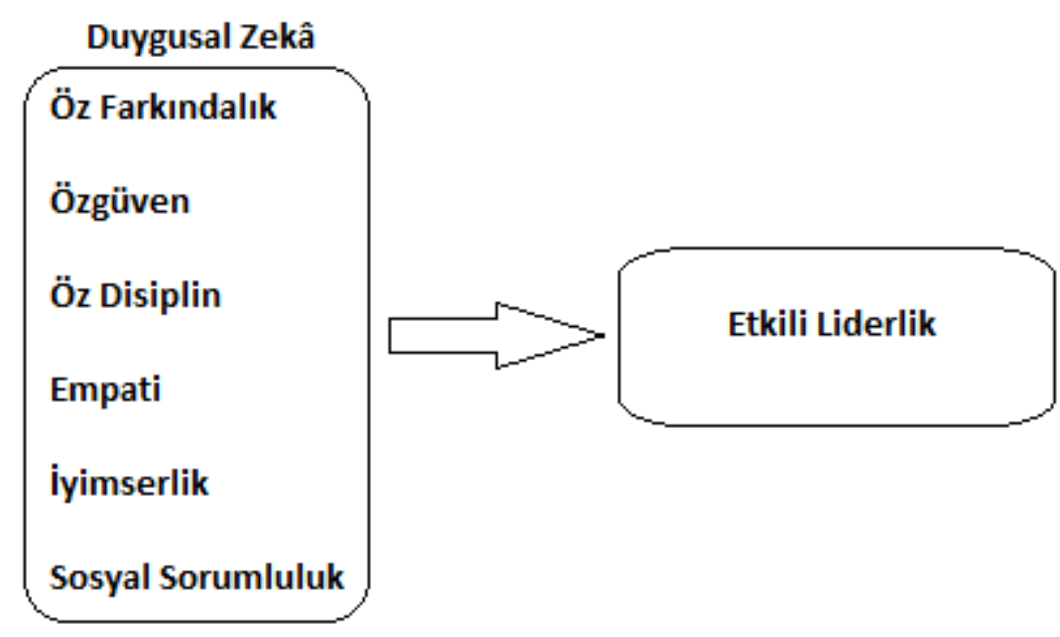

Şekil 2. Araştırmanın Modeli

Araştırmada veriler anket yöntemi yardımıyla toplanmış olup söz konusu anket formu üç bölümden oluşmaktadır. İlk bölümde katılımcıların betimsel analizini ortaya koymak üzere bir takım demografik özelliklere ilişkin ifadeler, ikinci bölümünde duygusal zekâ ile ilgili ifadeler, üçüncü bölümde ise etkili liderlik ile ilgili ifadeler yer almaktadır.

Bu bağlamda katılımcıların duygusal zekâ düzeylerini ölçmek amacıyla Cook vd.nin (2012) "Emotional İntelligence" ölçeğinden faydalanılmıştır. Söz konusu ölçekte duygusal zekâ altı alt boyutta ele alınmıştır. Bunlar; öz-farkındalık (self-awareness), özgüven (self-confidence), öz-disiplin (self-discipline), empati (empathy), iyimserlik (optimism) ve sosyal sorumluluk (social responsibility) şeklinde gruplandırılmışır. Örneğin "Olumlu veya olumsuz duygularımı gösterdiğimde bu duyguların etrafımdakileri nasıl etkilediğini farkedebilirim." ifadesi öz-farkındalık boyutunda yer almakta; "Beni kızdıracak ya da sinirlendirecek bir durumla karşılaştı̆̆ımda kısgınlığımın üstesinden gelebilirim ve kızgınlığımı denetim altına alabilirim." ifadesi öz-disiplin boyutunda yer alırken; "Grup içinde potansiyel bir çatışma söz konusu olduğunda ortak sorun çözme ya da anlaşma yolları bulmaya çalışırım." ifadesi sosyal sorumluluk boyutunda yer almaktadır.

Katılımcıların etkili liderlik düzeylerini ölçmek için Bass ve Avolio'nun (1996) “Multifactor Leadership Questionnaire - MLQ" ölçeğinden faydalanılmıştır. İfadelerden birkaçına örnek vermek gerekirse "etrafımda olan insanların iyi hissetmelerini sağlarım. İnsanlara karmaşık durumlarla karşılaştıklarında yeni yollar sunarım. İnsanların işlerini anlamlı bulmalarına yardımcı olurum. İnsanları başarı elde edebilecekleri konulara yönlendiririm."

Araştırmada ölçeklerde kullanılan ifadeler 5'li likert tipi ölçek yardımıyla değerlendirilmiş olup, değerlendirmeler Hiçbir zaman (1), Ara sıra (2), Sık sık (3), Çoğunlukla (4), Her zaman (5) şeklinde yapilmıştır.

Ölçeklerin güvenilirlik analizleri yapılmış olup güvenilirlik katsayıları (Cronbach's Alpha) Tablo 2'de gösterilebilir;

Tablo 2. Ölçeklerin Güvenilirlik Katsayıları

\begin{tabular}{|l|c|c|}
\hline & Duygusal Zekâ & Etkili Liderlik \\
\hline Türkiye & 0,815 & 0,872 \\
\hline Afganistan & 0,710 & 0,797 \\
\hline
\end{tabular}

Katılımcılardan elde edilen veriler SPSS 11.5 programından yararlanılarak analiz edilmiştir. Analizlerde Frekans Analizi, Korelasyon Analizi ve Doğrusal Regresyon Analizinden faydalanılmıştır. 


\section{B. Aydıntan - N. Künye - H. Ghafourzay 11/2 (2019) 976-989}

\section{Bulgular}

Çalışma, Türkiye ve Afganistan'da bankacılık, eğitim (üniversite), savunma, sağlık gibi kamu ve özel kesimde yer alan çeşitli sektörler üzerinde yapılmış olup söz konusu katılımcıların betimleyici istatistikleri aşağıdaki tabloda verilmiştir.

Tablo 3.Katılımcıların Cinsiyetlerine Göre Dağılımı

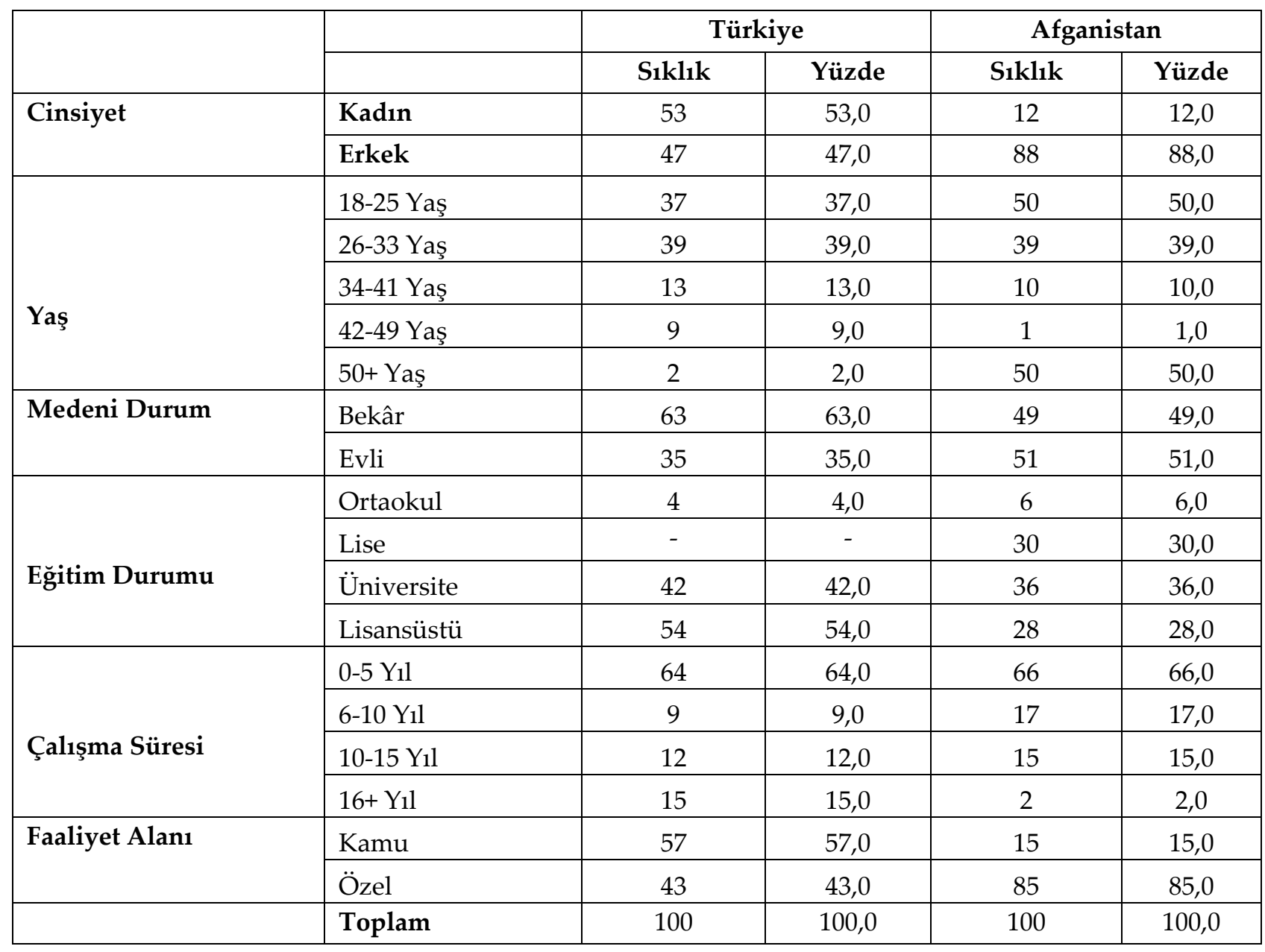

Betimleyici istatistiklere bakıldığında Tükiye'deki katılımclların \%53'ünün kadın \%47'sinin erkek olduğu; Afganistan'daki katılımcıların ise \%1'sinin kadın \%88'nin erkek katılımcı olduğu görülmektedir. Hem Türkiye hem de Afganistan için katılımcıların \%70'inden fazlasının yaş aralığının 18-33 yaş aralığında olduğu görülmektedir. Eğitim düzeylerine bakıldığında Türkiye'deki katılımcların 96'sının lisans ve lisansüstü mezunu olduğu, Afganistan'daki katılımcıların 30'u lise, 36'sı lisans ve 28'i lisansüstü mezunu olduğu görülmektedir. Faaliyet alanı olarak Türkiye'de kamu kesiminde çalışan katılımcılar daha fazla iken (\%57'si kamu kesim) Afganistan'da özel kesimde çalışan katılımcllar daha fazla (\%85'i özel kesim) olmuştur.

Diğer yandan korelasyon analiziyle duygusal zekânın ve duygusal zekânın alt boyutları ile etkili liderlik arasındaki ilişki test edilmiştir.

Tablo 4. Genel Korelasyon Tablosu (Türkiye)

\begin{tabular}{|l|c|c|}
\hline & Duygusal Zekâ & Etkili Liderlik \\
\hline Duygusal Zekâ & 1 & 1 \\
\hline Etkili Liderlik & $0,631^{* *}$ & 1 \\
\hline
\end{tabular}

${ }^{*} 0,05$ anlamlılık düzeyi.

${ }^{* *} 0,01$ anlamlılık düzeyi.

Seçilen örneklem bazında Türkiye için Tablo 4'de genel korelasyon tablosuna bakıldığında duygusal zekâ ile etkili liderlik arasında \%63,1 $\left(0.631^{* *}\right)$ düzeyinde anlamlı bir ilişki olduğu görülmektedir. 
Tablo 5. Ayrıntılı Korelasyon Tablosu (Türkiye)

\begin{tabular}{|l|c|c|c|c|c|c|c|}
\hline & $\mathbf{1}$ & $\mathbf{2}$ & $\mathbf{3}$ & $\mathbf{4}$ & $\mathbf{5}$ & $\mathbf{6}$ & $\mathbf{7}$ \\
\hline 1.Öz Farkındalık & 1 & & & & & & \\
\hline 2.Özgüven & 0,182 & 1 & & & & & \\
\hline 3.Öz Disiplin & $0,394^{* *}$ & $0,247^{*}$ & 1 & & & & \\
\hline 4.Empati & $0,455^{* *}$ & $0,302^{* *}$ & $0,383^{* *}$ & 1 & & & \\
\hline 5.İyimserlik & $0,355^{* *}$ & $0,375^{* *}$ & $0,316^{* *}$ & $0,386^{* *}$ & 1 & & \\
\hline 6.Sosyal Sorumluluk & $0,311^{* *}$ & $0,338^{* *}$ & $0,372^{* *}$ & $0,379^{* *}$ & $0,394^{* *}$ & 1 & \\
\hline 7.Etkili Liderlik & $0,347^{* *}$ & $0,346^{* *}$ & $0,356^{* *}$ & $0,337^{* *}$ & $0,530^{* *}$ & $0,625^{* *}$ & 1 \\
\hline
\end{tabular}

${ }^{*} 0,05$ anlamlılık düzeyi. ${ }^{* *} 0,01$ anlamlılık düzeyi.

Seçilen örneklem bazında Türkiye için Tablo 5'te korelasyon değerleri değerlendirildiğinde tüm boyutlar arasında pozitif yönlü bir ilişki olduğu görülmektedir. Öz-farkındalık ile özgüven arasında anlamlı bir ilişki bulunamamıştır. Diğer duygusal zekâ alt boyutları birbirleriyle anlamlı pozitif yönde ilişkilidirler. Diğer yandan öz-farkındalık ile etkili liderlik arasında \%34,7 $\left(0,347^{* *}\right)$ oranında anlamlı bir ilişki olduğu görülmekte olup öz-farkındalığı yüksek olan bireylerin etkili liderlik konusunda etkin bir role sahip olduğu söylenebilir. Özgüven ile etkili liderlik arasında \%34,6 $\left(0.346^{* *}\right)$ oranında anlamlı bir ilişki ortaya çıkmış ve buradan etkili liderlikte özgüveni yüksek olan bireylerin başarılı olduğu sonucuna varılabilir. Öz-disiplin ile etkili liderlik arasında \%35,6 $\left(0.356^{* *}\right)$ oranında anlamlı bir ilişki olduğu görülmektedir. Empati ile etkili liderlik arasındaki ilişki \%33,7 $\left(0.337^{* *}\right)$ oranında olup bu yönde etkili liderin empati duygusunun gelişmiş olması beklenmektedir. İyimserlik ile etkili liderlik arasındaki ilişkiye bakıldığında \%53 $\left(0.530^{* *}\right)$ oranında anlamlı bir ilişki olduğu görülmekte buradan da etkili liderin iyimser bir yapıda olmasının olumlu bir etkisinin olacağı sonucuna varılabilir. Son olarak etkili liderlik ile duygusal zekâ boyutları arasında en fazla ilişki \%62,5 $\left(0.625^{* *}\right)$ oranında sosyal sorumluluk boyutunda gerçekleşmiştir. Buradan etkili liderin sosyal sorunlar üzerinde çalışmalar yapması için sosyal sorumluluk bilincinin yüksek olması beklenmektedir yorumu yapılabilir. Türkiye örneklemi sonuçları için genel bir değerlendirme yapıldığında etkili liderliğin en fazla ilişkide bulunduğu duygusal zekâ boyutu \%62,5 oranında sosyal sorumluluk, en az ilişkide olduğu duygusal zekâ boyutu \%34,6 oranında özgüven olmuştur.

Tablo 6. Genel Korelasyon Tablosu (Afganistan)

\begin{tabular}{|l|c|c|}
\hline & Duygusal Zekâ & Etkili Liderlik \\
\hline Duygusal Zekâ & 1 & 1 \\
\hline Etkili Liderlik & $0,590^{* *}$ & 1 \\
\hline
\end{tabular}

${ }^{*} 0,05$ anlamlılık düzeyi. ${ }^{* *} 0,01$ anlamlılık düzeyi.

Afganistan örneklemi için genel korelasyon tablosuna bakıldığında duygusal zekâ ile etkili liderlik arasında $\% 59\left(0.590^{* *}\right)$ oranında anlamlı bir ilişki olduğu görülmektedir.

Tablo 7. Ayrıntılı Korelasyon Tablosu (Afganistan)

\begin{tabular}{|l|c|c|c|c|c|c|c|}
\hline & $\mathbf{1}$ & $\mathbf{2}$ & $\mathbf{3}$ & $\mathbf{4}$ & $\mathbf{5}$ & $\mathbf{6}$ & $\mathbf{7}$ \\
\hline 1.Öz Farkındalık & 1 & & & & & & \\
\hline 2.Özgüven & 0,064 & 1 & & & & & \\
\hline 3.Öz Disiplin & $0,296^{* *}$ & $0,246^{*}$ & 1 & & & & \\
\hline 4.Empati & $0,257^{* *}$ & 0,117 & 0,168 & 1 & & & \\
\hline 5.İyimserlik & 0,145 & $0,237^{*}$ & $0,320^{* *}$ & $0,202^{*}$ & 1 & & \\
\hline 6.Sosyal Sorumluluk & 0,168 & $0,207^{*}$ & $0,328^{* *}$ & 0,194 & $0,374^{* *}$ & 1 & \\
\hline 7.Etkili Liderlik & $0,264^{* *}$ & $0,333^{* *}$ & $0,284^{* *}$ & $0,319^{* *}$ & $0,522^{* *}$ & $0,390^{* *}$ & 1 \\
\hline
\end{tabular}

${ }^{*} 0,05$ anlamlılık düzeyi. ${ }^{* *} 0,01$ anlamlılık düzeyi.

Seçilen örneklem bazında Afganistan için Tablo 7'de korelasyon değerleri değerlendirildiğinde tüm boyutlar arasında pozitif yönlü bir ilişki olduğu görülmektedir Bu bağlamda Tablo 7'ye bakıldığında öz- farkındalık ile özgüven arasındaki ilişki Türkiye örneklemi sonuçlarıyla aynı çıkmış olup anlamlı bir ilişki 


\section{B. Aydıntan - N. Künye - H. Ghafourzay 11/2 (2019) 976-989}

bulunamamıştır. Yine öz-farkındalık ile iyimserlik ve sosyal sorumluluk arasında anlamı bir ilişkiye rastlanamamıştır. Benzer şekilde empati ile özgüven ve öz disiplin ve sosyal sorumluluk arasında da anlamlı bir ilişkiye rastlanamadığı görülmektedir. Bununla beraber öz disiplin ile öz farkındalık arasında $\left(0,296^{* *}\right)$ ve öz disiplin ile özgüven arasında $\left(0,246^{*}\right)$ anlamlı bir ilişki olduğu görülmektedir.

Etkili liderlik ile duygusal zekânın alt boyutları arasında pozitif yönlü anlamlı bir ilişki bulunmaktadır . Öz farkındalık ile etkili liderlik arasında $\% 26,4\left(0,264^{* *}\right)$ oranında pozitif yönlü zayıf bir ilişki bulunmaktadır. İyimserlik ile etkili liderlik arasındaki ilişki düzeyi $\% 52,2\left(0,522^{* *}\right)$ oranında olup orta düzeydedir. Genel bir değerlendirme yapıldığında etkili liderliği en fazla etkileyen duygusal zekâ boyutu \%52,2 oranında iyimserlik, en az etkileyen duygusal zekâ boyutu \%26,4 oranında öz farkındalık olmuştur.

Türkiye ve Afganistan örneklemleri için sonuçlar değerlendirildiğinde, korelasyon matrisinde açıklayıcı değişkenler arasında çok yüksek oranda korelasyona rastlanmamıştır, dolayısıyla modelde çoklu doğrusal bağlantı problemi yoktur.

Aşağıda Tablo 8'de Türkiye örneklemi için duygusal zekâ düzeyleri ile etkili liderlik arasındaki regresyon analizi verilmiştir. Regregresyon modelinin p değeri 0.000 çıkmıştır yani duygusal zekâ düzeylerinin etkili liderliği istatistiksel olarak açıklayabildiğini göstermektedir.

Tablo 8. Duygusal Zekâ Düzeyleri ile Etkili Liderlik Arasında Regresyon Analizi (Türkiye)

\begin{tabular}{|l|c|c|c|c|}
\hline Bağımsız Değişkenler & Beta & $\mathbf{t}$ & Sig. & VIF \\
\hline Öz Farkındalık & 0,079 & 0,912 & 0,364 & 1,410 \\
\hline Özgüven & 0,062 & 0,757 & 0,451 & 1,254 \\
\hline Öz Disiplin & 0,059 & 0,688 & 0,493 & 1,352 \\
\hline Empati & $-0,025$ & $-0,274$ & 0,785 & 1,487 \\
\hline İyimserlik & 0,292 & 3,346 & 0,001 & 1,414 \\
\hline Sosyal Sorumluluk & 0,452 & 5,224 & 0,000 & 1,386 \\
\hline
\end{tabular}

Bağımlı Değişken: Etkili Liderlik. Düzeltilmiş $R^{2}=0,466 \quad F=15,426$ Sig. $=0,000$

Türkiye örneklemi için regresyon sonuçlarına bakıldığında belirlilik düzeyinin (Düzeltilmiş $\mathrm{R}^{2}$ ) 0,466 olduğu görülmektedir. Bunun anlamı duygusal zekâ düzeylerinin etkili liderliğin yaklaşık \%47'sini açıklamasıdır.

Tablo 8'e bakıldığında duygusal zekâ boyutlarından sosyal sorumluluk ve iyimserliğin etkili liderlik üzerinde anlamlı bir etkiye sahip olduğu görülmektedir.

Aşağıda Tablo 9'da Afganistan örneklemi için duygusal zekâ düzeyleri ile etkili liderlik arasındaki regresyon analizi verilmiştir. Regregresyon modelimizin p değeri 0.000 çıkmıştır yani duygusal zekâ düzeylerinin etkili liderliği istatistiksel olarak açıklayabildiğini göstermektedir.

Tablo 9. Duygusal Zekâ Düzeyleri ile Etkili Liderlik Arasında Regresyon Analizi (Afganistan)

\begin{tabular}{|l|c|c|c|c|}
\hline Bağımsız Değişkenler & Beta & $\mathbf{t}$ & Sig. & VIF \\
\hline Öz Farkındalık & 0,051 & 1,503 & 0,136 & 1,156 \\
\hline Özgüven & 0,062 & 2,187 & 0,031 & 1,110 \\
\hline Öz Disiplin & 0,059 & 0,039 & 0,969 & 1,290 \\
\hline Empati & 0,055 & 1,860 & 0,066 & 1,120 \\
\hline İyimserlik & 0,060 & 4,053 & 0,000 & 1,265 \\
\hline Sosyal Sorumluluk & 0,057 & 1,795 & 0,076 & 1,258 \\
\hline
\end{tabular}

Bağımlı Değişken: Etkili Liderlik. Düzeltilmiş $\mathrm{R}^{2}=0,362 \quad \mathrm{~F}=10,380$ Sig. $=0,000$ 


\section{B. Aydıntan - N. Künye - H. Ghafourzay 11/2 (2019) 976-989}

Afganistan örneklemi için regresyon sonuçlarına bakıldığında belirlilik düzeyinin (Düzeltilmiş $R^{2}$ ) 0,362 olduğu görülmekte bu da duygusal zekâ düzeylerinin etkili liderliğin yaklaşık \%37'sini açıklamaktadır. Tablo 9'a bakıldığında etkili liderlik üzerinde duygusal zekânın boyutlarından özgüven, empati, iyimserlik ve sosyal sorumluluk boyutlarının etkili olduğu görülmektedir.

\section{Sonuç}

Duygusal zekânın etkili liderlik üzerindeki etkisini incelemek amacıyla Türkiye ve Afganistan'da bankacılık, eğitim (üniversite), savunma, sağlık gibi kamu ve özel kesimde yer alan çeşitli sektörler üzerinde yapılmış olan bu çalışmada, çalışmanın "H1: Duygusal zekânın etkili liderlik üzerinde etkisi vardır." hipotezi kabul edilmiştir.

Araştırmada elde edilen analizler neticesinde her iki ülke örnekleminde de (Türkiye ve Afganistan) duygusal zekâ ve etkili liderlik arasında anlamlı pozitif yönlü bir ilişki görülmüştür (Türkiye için \%63,1 ve Afganistan için \%59 düzeyinde ilişki). Her iki ülke örnekleminde de duygusal zekânın etkili liderlik üzerinde bir etkisi olduğu ortaya çıkmıştır. Duygusal zekânın etkili liderliği etkilemesindeki fark, ülkelerarasında duygusal zekânın alt boyutları açısından olmuştur. Türkiye örneklemi için bakıldığında etkili liderlik üzerinde duygusal zekâ boyutlarından sosyal sorumluluk ve iyimserliğin etkili liderlik üzerinde anlamlı bir etkiye sahip olduğu görülmektedir. Afganistan örneklemi için bakıldığında etkili liderlik üzerinde duygusal zekânın boyutlarından özgüven, empati, iyimserlik ve sosyal sorumluluk boyutlarının etkili olduğu görülmektedir.

Bu çalışma, duygusal zekâ ve duygusal zekânın alt boyutlarının etkili liderlik üzerindeki etkisini göstermesi açısından önemlidir. İleride bu konuda çalışma yapmak isteyenler, duygusal zekâyla benzerliği olan ve kimi zaman karıştırılan sosyal zekâ kavramıyla etkili liderlik arasındaki ilişkiyi araştıran bir çalışma yapılabilirler.

Duygusal zekânın etkili liderlik üzerindeki etkisi incelenirken başka bir aracı değişken olarak kişilik ve kişilik özellikleri, etkili ve etkili olmayan liderliği birbirinden ayırmak açısından kullanılabilir.

\section{Kaynakça}

Adair, J. (2003). Esin Veren Lider. Dharma Yay. (1. Bas.), İstanbul.

Bar-On, R., Ciarroch1, J., Forgas, J.P. and Mayer, J.D. (2001). Emotional intelligence and self-actualization. Emotional Intelligence in Everyday Life : 82-97. Philadelphia, Taylorand Francis.

Bar-On, R. (2001). The Bar-On Model of Emotional- Social Intelligence-ESI. Psicothema, 18, supl., 13-25.

Bass, B. M. \& AVOLIO, B. J. (1996). MLQ Multifactor Leadership Questionnaire For Teams. Redwood City, CA: Mind Garden.

Bass B. M. (1997). Does The Transactional - Transformational Leadership Paradigm Transcend Organizational and National Boundaries? Amarican Psychological Association. Vol. 52. No.2. pp.130139.

Beceren, E. (2012). Duygusal ve sosyal Zekâmız. Postiga Yay. (1. Bas.), İstanbul.

Bloch, S. ve Whiteley, P. (2007). Kusursuz Liderlik. Liderlik Yeteneklerinizi Geliştirme Klavuzu. Optimist Yay. (1. Bas.), İstanbul.

Cook, S. And Macaulay, S. and Coldicott, H. (2012). Change Management Excellence: Using the Four Intelligences for Successful Organizational Change. Kogan Page Publish. London.

Cooper, R.K. ve Sawaf, A. (1997). Applying Emotional İntelligence in the Workplace. Training \& Development. 51.12. pp.31+. 


\section{B. Aydıntan - N. Künye - H. Ghafourzay 11/2 (2019) 976-989}

Doğan, S. ve Şahin, F. (2007). Duygusal Zekâ: Tarihsel Gelişimi ve Örgütler İçin Önemine Kavramsal Bir Bakış. Ç.Ü. sosyal bilimler Enstitüsü Dergisi, C.16, S.1.

Downey, L.A., Papageorgiou, V. and Stough, C. (2005). Examinin The Relationship Between Leadership, Emotional İntelligence and İntution in Senior Female Managers. Leadership \& Organization Development Journal. V.27. N.4.pp.250-264.

Erkuş, A. ve Günlü, E. (2008). Duygusal Zekânın Dönüşümcü Liderlik Üzerine Etkileri. İşletme Fakültesi Dergisi, C.9, S.2. ss.187-209.

Fiedler, F.E. (1981). Leadership Effectiveness. American Behavioral Scientist. Vol.24. No.5.pp.619-632.

Gardner, L. ve Stough, C. (2002). Leadership \& Organization Development Journal. Vol.23. Issue.2.pp. 68-78.

Girdauskiene, L. ve Eyvazzade, F. (2015). The Profile of an Effective Leadership in Multicultural Context. Social and Behavioral Sciences 210 .pp.11 - 20.

Goleman, D. (2003). Duygusal Zekâ Neden IQ'dan Daha Önemlidir? Varlık /Bilim Yay. (23. Bas.), (Çev. Banu Seçkin Yüksel), İstanbul.

Goleman, D. (2007). Sosyal Zekâ. Varlık Yay. (1. Bas.), İstanbul.

Goleman, D. (2002). Yeni Liderler. Varlık Yay. (4. Bas.), İstanbul.

Goleman, D. And Boyaztzis, R. (2008). Social İntelligence and the Biology of Leadership. Harvard Business Rewiew. Vol. September-2008.pp.2-7.

Goetsch, D. L. (2005). Effective Leadership. Ten Steps for Technical Professions. Pearson Prentice Hall Pub. New Jersey.

House, R.J. 1996. Path-Goal Theory of Leadership: Lessons, Legacy, and a Reformulated Theory. The Leadership Quarterly. Vol,7. Issue 3. Pp 323-352.

Imboden, S. (2014). Food Safety Management. A Practical Guide for the Food Industry. Edited: Yasmine Motarjemi and Huub Lelieveld. Elsevier B.V.Publish.

Katz, D. ve Kahn, R.L. (1977). Örgütlerin Toplumsal Psikolojisi. Türkiye Orta Doğu ve amme İdaresi Enstitüsü Yay. N0.167 (Çev. Halil Can ve Yavuz Bayraktar), Doğan Basımevi, Ankara.

Kets de Vries, M. (2007). Liderliğin Gizemi. İşletmelerde Liderlik Davranışı. (Çev. Zülfü Dicleli). Türkiye Metal Sanayicileri Sendikası Yay. İstanbul. (Eserin Orijinali Prentice Hall, Financial Times.

Kılıçarslan, F. (2010). 10 Adımda Duygusal Zekâ. Yaşam Boyu Başarıyı Yakalamanın Sırları. Nobel yay. (2. Bas.), Ankara.

Leban, W. and Zulauf, C. (2004). İntelligence Abilities and Transformational Leadership Style. The Leadership \& Organization Development Journal. V.25. N.7.pp.554-564.

Mayer, J.D. ve Salovey, P. (1990). Emotional İntelligence. Imagination, Cognition and Personality, Vol. 9. Issue.3.pp. 185-211.

Mayer, J.D., Caruso, D.R. and Perkins, D. (2001). Emotional İntelligence and Giftedness. Journal Roeper Review. Vol.23. Issue 3. Pp.131-137.

McKeown, A. and Bates, J. (2013). Emotion İntelligent Leadership Findings from Study of Public Library Branch Managers in Northern Ireland. Library Management. Vol.34. No.6/7. pp.462-485.

Palmer, B. \& Walls, M. \& Burgess, Z. \& Stough, C. (2001). Emotional intelligence and effective leadership. Leadership \& Organization Development Journal, Vol. 22 Issue: 1, pp.5-10. 
B. Aydıntan - N. Künye - H. Ghafourzay 11/2 (2019) 976-989

Riggio, R.E. ve Reichard, R.J. (2008). The Emotional and Social İntelligences of Effective Leadership. An Emotional and Social Skill Approach. Journal of Managerial Psychology. Vol.23. No.2. pp.169-185.

Robbins, S. and Judge, T.A. (2015). Organizational Behavior. Pearson Pub.(16.Edit.). USA.

Tarhan, N. (2014). Duyguların Psikolojisi. Timaş Yay. (16. Bas.), İstanbul.

Titrek, O. (2010). IQ'dan EQ’ya. Duyguları Zekice Yönetme. Pegem Akademi Yay. (2. Bas.), Ankara.

Wexley, K.N. and Yukl, G. (1977). Organizational Behavior and Personnel Psychology. Irwin-Dorsey Ltd. USA.

Yukl, G. (1999). An Evaluative Essay on Current Conceptions of Effective Leadership. European Journal Of Work And Organızatıonal Psychology, 1999, Effectıve Leadershıp.8(1), 33-48.

Yukl, G. (2012). Effective Leadership: What we Know and What Questions Need More Attention. Academy of Management Executive.26(4):66-85.December.

Yukl, G. (2013). Leadership in Organization. Pearson Publish. (8. Edit.), Westford in USA. 